\title{
READERS
Insight
}

\author{
Journal of Research in Psychology (JRP) \\ www. readersinsight.net/jrp \\ ISSN: 2664-9500 (Online) \\ ISSN: 2664-9497 (Print)
}

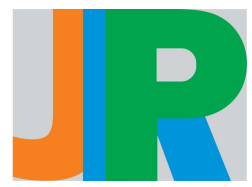

\section{Learning and Facilitation (PdPc) Islamic Education in Industrial Revolution 4.0}

\author{
Muhammad Talhah Ajmain@Jima'ain ${ }^{1 *}$, Aminudin Hehsan², Ahmad Marzuki Mohamad ${ }^{3}$ \\ 1-3 Islamic Civilisation Academy, Universiti Teknologi Malaysia, 81310, Johor Bahru, Johor \\ * Corresponding author: mtalhah.uda@gmail.com
}

\begin{abstract}
A challenge that usually occurred in the education system nowadays is to adapt to learning and facilitating $(\mathrm{PdPc})$ for facing the upcoming industrial revolution 4.0. Industrial Revolution 4.0 give big impacts to teachers to develop a group of students that have high skills, critical thinking, and emotional wellbeing. Islamic education teachers need to take action based on industrial revolution 4.0, creative and innovative using any media and sources to produce interesting $(\mathrm{PdPc})$.This writing for discussing PdPc of Islamic Education that relevant to the concept of industrial revolution 4.0 by adapting Learning Skills of $21^{\text {st }}$ Century, authentic learning, soft skills, and Critical Thinking Skills(HOTS).It also discusses of challenge that teachers faced in running the Islamic Education learning towards industrial revolution 4.0.
\end{abstract}

Article Information:

Received: $\quad 25^{\text {th }}$ March 2019

Revised: $15^{\text {th }}$, Aug 2019

Accepted: $\quad 3^{\text {nd }}$ Sep 2019

\section{Introduction}

Industrial Revolution 4.0 (IR 4.0) changes the world economy nowadays from the conventional economy which based on resources into a digital economy where everything depends on tech-industries. Industrial Revolution 4.0 will changes our ways of life and human trends of work that use the internet as a requirement in every sector of the economy, politics, and society. The changes consist of three main domain of technology such physical,digital and biological consist of 9 pillars which is simulation and virtual reality,integration system vertical and horizontal,Internet of Thing industrial (IoT),cybersecurity,cloud computing,additional material manufacture, chain provider,data analysis and an automation robot (Klaus Schwab, 2015; Anne Marie, 2018). Group of worker that consist of high skills, efficient and effective highly demands to cope together with robots even other automation systems to speed up the process of production and productivity(Noor Mohamad Shakil Hameed, 2018).

In order to confront the Industrial Revolution 4.0 (IR 4.0), education based on 4.0 needs to be adept in every subject. Integration of Islamic Education in Education of Science, Technology, Engineering and Mathematics (STEM) to STEAM shows that education is very important and worthy. Personality and humanity are the basics in the system IR4.0 system. Teachers need to do PdPc so the product soon will provide students that have high skills, creative, innovative and manage to produce a high-quality product that can compete internationally. The key to awakening the potential is the whole-life learning that inter-discipline, inter-function,inter-industry, and inter-culture.

\section{Literature review}

Learning and Facilitating (PdPc) Islamic Education and Industrial Revolution 4.0 (IR 4.0)

There are many courses and skills in Islamic Education curriculum. In the stage of Primary Schools, Islamic Education Field consists of four component which is Tilawah Al-Quran, Basic of Ulum Syariah (Aqidah, Ibadah, and Sirah, Basis of Islamiah and Jawi Education). While Secondary Schools, the subject of Al Quran, Hadis, Aqidah, Fiqah, Field of Sirah and Islamic Civilization, also the field of Akhlak (KSSM, 2016).The goal of Islamic Education is to build and shaping the servants and khalifah of Allah who full of knowledge, have iman, taqwa, always doing good deeds, nice manner and their character based on Al Quran and al-Sunnah and contributes towards build up nation and country to prosperity to achieve success in this world and hereafter.

This good desire will happen through Learning and Facilitating (PdPc) Islamic Education that corresponding to needs of time even with the provided syllabus of education. If not, the subject will be left behind and not giving any meaning to the students. Islamic Education Method needs to be taught by the culture of Malaysia in the line of Pelan Pembangunan Pendidikan Malaysia 2013-2025, Transformasi Nasional (TN50) and Transformasi Sekolah (TS 25). Therefore, Teachers need to be creative and innovative using a suitable source and media to produce PdPc that more interesting. One of the thing that discussed in this writing is learning the application of $21^{\text {st }}$ century, Critical Thinking Skills(HOTS).soft skills, authentic learning that 
provides students with high skills, critical thinking and can solve problems, communicate, collaboration, creativity, and emotional wellbeing.

\section{Learning Skills Of 21st Century}

Learning Skills of the $21^{\text {st }}$ century (PAk 21) focusing on four main principles consist of critical thinking and problem solving, communication, collaboration, creativity (KPM, 2012). Adaption skills (PAk 21) can help students through the challenge of life nowadays and more confidence in the career field. Several pieces of research show the influence of $21^{\text {st }}$-century learning give positive impact in manner, motivation and achievements of the students (Masyuniza Yunos, 2015; Ainun Rahmah Ibrahim et al., 2017). The success of $21^{\text {st }}$ learning approach is dependent on the intelligence of teachers as professionals that can integrate knowledge practical in PdPc (Rohani Arbaa et al., 2017).

There are many approach of (PAk 21) that can be done and suitable in Islamic Education one of it by project approach, cooperative learning, gallery walk, hot seat, blended learning, think pair share and etc:-. For example, Like gallery walk, teachers can do it and provide chances for students to show their work in class. Students will move from another to another for listening to their friends' explanation. ( experience, creativity, the technique used) Then judging the work and state lesson they get from the masterpiece.In the activity, students will practice to communicate, do reflection, judging and relate it with life unconditionally in parallel with education 4.0. Abersek (2017).

Computer and internet usage were encouraged in PdPc of the $21^{\text {st }}$ century because it shows the student the principle of Industrial Internet of Things (IoT). For example, the title is the production of food packaging. At the early stage, teachers can ask students to find related information from the internet, newspaper, magazine and food packaging itself. Information collected can give awareness about the method, materials, technique and suitable design for that situation. Next stage, students will sketch the idea and are guided by using a computer to relate it with the search and associate it with learning as well as with life.The outcome using this IoT will teach students effectively for creating a visual image that creative, image contains expressive energy, coherence, and encourage smart thinking also show PdPc Islamic Education that follows as time goes by. This approach shows the critical activity and students creative artwork authentically. As Chapman (1978) said, a learning process that shows artwork will consist of artistic process and emphasizing on generate of the idea, manipulation, purification of the idea and emphasize of skills in using the material. Therefore, in this context, PdPc PAk 21 is the success and it correlates to education 4.0 because students can enhance their creativity, analytical skills, and interpersonal skills, potential to know and information processing skills as suggested by Abersek (2017). Table 1 shows the competency of PAk 21 in context of education 4.0 that adapt to Islamic Education.

\begin{tabular}{|c|c|c|c|c|}
\hline $\begin{array}{l}\text { Analytical } \\
\text { Skills }\end{array}$ & $\begin{array}{l}\text { Interpersonal } \\
\text { Skills }\end{array}$ & $\begin{array}{l}\text { Ability } \\
\text { to } \\
\text { realizing } \\
\end{array}$ & $\begin{array}{l}\text { Information } \\
\text { Processing }\end{array}$ & $\begin{array}{l}\text { Ability to } \\
\text { changes/Learning }\end{array}$ \\
\hline \multirow[b]{2}{*}{ H4 } & \multirow{2}{*}{$\begin{array}{l}\mathrm{SC} \rightarrow \mathrm{BL} \\
\text { SC-Mod } \rightarrow \\
\text { BL }\end{array}$} & 0.131 & 0.021 & 6.268 \\
\hline & & 0.017 & 0.021 & 0.778 \\
\hline \multirow{3}{*}{ H5 } & \multirow{3}{*}{$\begin{array}{l}\text { SI } \rightarrow \text { BL } \\
\text { SI-Mod } \rightarrow \\
\text { BL } \\
\text { SL } \rightarrow \text { BL }\end{array}$} & 0.036 & 0.017 & 2.093 \\
\hline & & 0.071 & 0.018 & 4.057 \\
\hline & & 0.099 & 0.019 & 5.115 \\
\hline
\end{tabular}

Authentic Learning
Confronting IR 4.0, authentic learning is most required for students can use the knowledge that they acquired in the real situation. According to Wiggins (1998) and Rennert-Ariev (2005) authentic learning will affect teachers, student, and the relationship among teachers and students. Authentic learning must focus on knowledge, though, and skills that presented in the real world outside of the school to obtain good outcome, more typical and performance. Implementation a lot of learning strategy such portfolio, project approach, discovery inquiry can help students interact with the material, teachers and other students also enhance student's mastery in a lot of aspects such cognitive, affective and psychomotor. (Che Aleha Ladin, 2015). According to McMillan (2007), authentic learning and facilitating need to be associated with the assessment so student daily learning can be estimated consistently. The task given must focus on problem-solving then students finally can complete the task given as professionals in that field based on real context.

Several pieces of research find out authentic learning increase teachers and students level of confidence as a meaningful method in Education Pendididikan (Azimah A. Samah, 2016; Che Aleha Ladin, 2015; Russell \& Deirdre, 2012; Lawrence,n.d). Russell \& Deirdre (2012) as an example, already developed the confidence of amateur teachers for primary schools in education by using authentic learning principle because they lack confidence, self-teaching ability, lack of resources, knowledge, and experience.

While Azimah A. Samah (2016) and Lauwrence (n.d) apply technology in lesson outcome and that method provide working experience in future towards IR 4.0. Azimah A Samah (2016) research emphasize in student assignment by implementation Digital Painting or Catan Digital. This practice can help average and weak students to produce high quality of paintings. There is an improvement in students image visual development in digital painting compared to conventional paintings that consist of four aspects such as composition, color manipulation, interpretation and creativity. Students are able to create digital painting after given a treatment that can stimulate cognitive development. (Intimacy between mind, eyes and existing knowledge), also bring the movement of psychomotor that been expressed in painting.

The application of digital technology in Islamic Education is positive. According to Kamarul Azmi Jasmi et al., (2012); Abdullah Ismail \& Daud Ismail (2018), Teachers with smart IT in Islamic Education were increasing and teenagers start to use it wisely. Even the IT is not fully implemented yet in PdPc, but this method offers many new exposure opportunities for students and the innovative that required in IR 4.0.

The use of technology in the above-mentioned authentic contexts exposes students to produce high-quality artwork, overcoming weaknesses if did by manual and time-saving. Therefore, knowledge related to pedagogical technology and knowledge content is crucial to fill in the needs of the work in the future. A study by Roslaili Anuar \& Zamani Zakaria (2015) found that UiTM's education students are ready to learn to use technology easily and have the necessary technical skills in Educational learning. The majority of students agree that they have sufficient knowledge content and can think of various ways to use technology to develop Educational understanding.

\section{The Application Of Soft Skills}

Challenge and impacts of technology need human resources that wisdom in terms of mind and soul aspect. The appearance of the Industrial Revolution 4.0 (IR 4.0) can decrease the sense of humanity if not overcome effectively. Soft skills are available in the context of 21st Century learning (Faizah Abdul Majid et.all, 2017) need to be applied in PdPc Education. It is an added value that can produce 
competent and outstanding human capital as contained in the Malaysia Education Blueprint 2013-2025.

There are seven soft skills namely communication skills, critical thinking and problem-solving skills, teamwork, lifelong learning, entrepreneurial skills, ethics and morals, professionalism and leadership skills (Nikitina \& Furuoka, 2012; KSSM, 2016). Based on the World Economic Forum (2016), the soft skills in the Industrial Revolution 4.0 involve 10 skills namely complex problem-solving skills, critical thinking, creativity, human management, relationships with others, emotional intelligence, judgment and decision making, service orientation, consultation and flexibility cognitive. Cotet et.all, (2017) lists the dimensions of the soft skills needed in the 4.0 industrial revolution which is interpersonal skills, personal affirmation, respect, self-strength, empathy, desire, perfectionism, self-discipline, intellectual curiosity, liberalism, freedom, and creativity.

A study conducted by Robles (2012) found that some weaknesses in the soft skills integration in the classroom were due to the workload of teachers, a lot syllabus and an uncertain approach to teaching soft skills. The teaching of soft skills is said to be very challenging as compared to the teaching of skills in academic subjects or hard skills. Groh et.al. (2016) also found it difficult to assess the changing of soft skills or the lack of skills to be an issue for the soft development effort. The application of soft skills can enhance engagement in learning and nurturing communication skills, critical thinking and creativity (KPM, 2017). Quality of teaching of teachers becomes an important factor that can promote effective learning in schools (Tang Keow Ngang, 2013).

Islamic education teachers need to integrate soft skills as elements across the curriculum (EMK) in every subject of teaching. For example, in the Islamic Education PdPc of Islamic History titled Science Scholars, Many activities can be done by teachers to apply soft skills such as interpersonal skills, personal affirmation, homage, selfesteem, desire, perfectionism, self-discipline, making self-exemplary examples and creativity relevant to education 4.0. Students are given the opportunity to study, explore and follow the exemplary character of the figure also the discovery of science by them as well. This process can enhance creativity and problem solving as well as enhance aesthetic awareness in the students. PdPc's effective education not only produces a lot of products but also links technology, history, and purity that can certainly foster the value of appreciation and cultural value within the student. By carrying out PdPc Islamic Education in groups, students are able to communicate (interpersonal skills), tolerance (tolerance), foster tolerance to beliefs, interfaith, ethnic and cultural attitudes that are respected with respect for each other. The resulting synthesis of teaching can be shared and applied outside of the classroom. The result of a 'value revolution' in Islamic Education that focuses on the need to transform conventional values to good values that universal from a broader perspective can be tackled.

\section{High Order Thinking Skills (HOTs)}

HOTs is a very important skill in education 4.0. PdPc Islamic education becomes more challenging and more meaningful in this century because the application of HOTS can produce trained and students that always ready to work, think creatively and critically to the extent of creating. According to Collins, R. (2014), the Zero Project developed at Harvard University, provides examples of how teachers can help students think about seeing the information. Students are asked to use six thought styles to define the art by exploring pointers, finding causes, questioning and investigating, observing and explaining, comparing and linking, and searching for complexity. Therefore, in Islamic Education PdPc in the classroom, the application of HOTS can be applied comprehensively regardless of the field of History, Fiqah, Aqidah, and Morals. The HOTS application also needs to be applied in the PdPc assessment process such as Brookhart's (2010) recommendation, in his book How to Assess Higher Order Thinking Skills in Your Classroom, the assessment should involve five skills such analyzing, evaluating and creating, evaluating, problem-solving, creativity and thought creative.

HOTS applications in education 4.0 can also be referred to based on Abersek's (2017) view: teachers need to find differences in interdisciplinary knowledge, using contemporary strategies involving problem-based learning, linking basic techniques and information technology communications in multiple disciplines. The education of RI 4.0 involves self-education, new solutions, and various ways of thinking. Therefore, Islamic Education teachers need to use contemporary methods or teaching and facilitating models (PdPc) as transdisciplinary models and problem-solving approaches combining how human learn (using the brain as a technique) so as to build cognitive and social competencies. Emphasis on critical thinking, creative thinking, and problem-solving, collaboration, cooperative learning, and dialogue are as a foundation that can build high-level cognition.

\section{Challenges For Islamic Education Teachers To Confront Industrial Revolution $\mathbf{4 . 0}$}

In facing the challenges of revolutionary education 4.0, what is the level of teacher preparation and current student? Are all areas of Islamic Education appropriate to maximized and trained by focusing on the context of RI 4.0?. This is because the Smith and Anderson reports (2014) find that 48\% experts imagine that in 2025, robots and digital agents will cause human unemployment, though $52 \%$ think technology will not replace jobs instead of believing that human intelligence will provide new jobs, a new way of life. If we confront with no sufficient knowledge and skills, we will be left out and unable to compete.

The main challenge which is how far our facilities provided perfectly by the school, Ministry of Education Malaysia especially in the rural area. To streamline our willingness to meet RI 4.0, UNESCO recommends existing facilities to be developed and streamlined, as students are now exposed to a world of digital technology-based, the internet, cloud computing, and social media that challenge the formal education system.

Aspects of teacher knowledge are important because not all teachers have the skills and have been exposed to technology tools to implement teaching innovation and facilitating in the classroom. The study conducted by Kamaruddin Ilias and Che Aleha Ladin (2018) found that the knowledge of trainee teachers towards the Industry 4.0 revolution was still at a moderate level. This shows the need for exposure from lecturers and students in particular who will be teachers because of the teachers who will reflect the future of the students. The change in the context of continuous learning and information management, especially the evolution of the Internet, is challenging traditional educational concepts and theories, especially towards classroom concepts and teaching and facilitating methods (PdPc). The impact of technology will change social relationships and future generations. When software programs are enhanced, the technologybased learning experience should also be mastered.

\section{Conclusion and Suggestion}

The development of the Industrial Revolution affects Islamic Education teachers to be more willing, creative and innovative to implement PdPc in the context of education 4.0. Teaching and facilitating Islamic Education requires a focused approach to collaborating and dependant from one with another. Active learning, project-based learning, problem-solving and discovery inquiries, and 
various 21 st-century learning methods should also be combined with the use of information technology as a tool for students to engage in authentic in the present context.

Teachers are no longer regarded as the primary source of information with the growing open-source of information and content online. Students who are more exposed to technology will make device tools as a learning medium. However, this does not mean teachers are not needed in the classroom, but the role has shifted from leadership style to a consultative leadership style. However, teachers remain the primary router and educator in education. Students are given the freedom in PdPc to adapt the learning process, guide and free information in the virtual world to enhance their knowledge. However, a technology-centered balance without abandoning the application of soft skills and thinking skills is also very important in Malaysia.

Therefore, Islamic Education teacher training programs need to be diversified, updated to meet educational challenges 4.0. Islamic Education teachers need to be creative, innovative to make learning more interesting relevant to the current context. Teachers of Islamic Education should also be wise to translate, plan and execute PdPc in the classroom so as to provide a learning sequence that is able to shape the student's experience to eventually contribute to the required workforce. Hence, in order to ensure that human education and the development of Islamic personalities in the lives of each student, Islamic education teachers need to be independent as well to monitor the use of the media of their students as much as possible, this is because the task of educating cannot be done by machines and robots only, it is still on the shoulders of man.

\section{References}

Abersek, B. (2017). Evaluation of competencies for a new era or education 4.0. The XXV Conference of Czech Educational Research Association (CERA/CAPV) "Impact of the technologies in the Sphere of Education and Educational Research" on 13-14 September 2017.

Afandi Ahmad (2017). Industri 4.0 ubah cara kerja, hidup. Berita harian Online. https://www.bharian.com.my/node/291781

Ainun Rahmah Iberahim, Zamri Mahamod \& Wan Muna Ruzanna Wan Mohamad. (2017). Pembelajaran abad ke-21 dan pengaruhnya terhadap sikap, motivasi dan pencapaian Bahasa Melayu pelajar sekolah menengah. Jurnal Pendidikan Bahasa Melayu, 7(2), 77-88

Anne Marie Engtoft Larsen. (2018). Knowledge Lead, Science and Technology Studies, World Economic Forum Geneva. https://www.weforum.org/events/world-economic-forum-annualmeeting

Azimah A. Samah. (2016). Penghasilan Catan Digital dalam Pendidikan Seni Visual murid tingkatan empat. Tesis Doktor Falsafah: Universiti Malaya.

Brookhart,S. (2010), How to Assess Higher Order Thinking Skills in Your Classroom, http://www.ascd.org/Publications/Books/Overview/How-toAssessHigher-Order-Thinking-Skills-in-Your-Classroom.aspx

Chapman, L.H.; (1978). Approaches to art in education. New York: Hurcourt College.

Che Aleha Ladin. (2015). Pentaksiran Berasaskan Sekolah Pendidikan Seni Visual sekolah Menengah. Tesis Doktor Falsafah. UPSI.

Collins, R. (2014). Skills for the 21st century: Teaching higher order thinking. Curriculum leadership Journal. An Electronic Journal for Leaders in education 12 http://www.curriculum.edu.au/leader/teaching higher_order thinking, 374 31.html?issue ID $=12910$

Cotet, G.B., Balgiu B.A \& Zaleschi, C. (2017). The assessment procedure for the soft skills requested by industry 4.0. MATEC Web of Conference 121.

Efland A. D. (1990). A history of art education; Intellectual and social/currents in the visual arts. New York : Teachers College

Eisner, E.W (2002). The educational imagination. On the design and evaluation of school programs (3rd ed). Upper Saddle Vally, NJ. Merill Prentice Hall.

Faizah Abdul Majid, Ainul Azmin Md Zamin \& Fauzi Kamaruddin. (2017). Toolkits for 21 st century teaching: Practical implications for the 4th industry skill developments. Shah Alam: Penerbit Press UiTM.
Feldman E. B. (1996). Philosophy of art education. Upper Saddle River NJ: Prentice Hall.

Groh M., Krishnan N., McKenzie D. \& Vishwanath T. (2016). The impact of soft skills training on female youth employment: evidence from a randomized experiment in Jordan. IZA Journal of Labor \& Development, 5:9

Jiř́ Balcar. (2014). Soft Skills and their Wage Returns: Overview of Empirical Literature. Review Of Economic Perspectives-Národohospodářský Obzor. Vol. 14(1), pp. 3-15, Doi:10.2478/Revecp-2014-0001

Kamaruddin Ilias \& Che Aleha Ladin. (2018). Pengetahuan dan kesediaan Revolusi Industri 4.0 dalam kalangan pelajar Institut Pendidikan Guru Kampus Ipoh. International Seminar on Education Issues (ISPEN).

Kamarul Azmi Jasmi Md Yusnan Lamat Azhar Muhammad Mohd Ismail Mustari Muhamad Faiz Ismail Mohd Faeez Ilias. (2012). Aplikasi Teknologi Dalam Pengajaran Dan Pembelajaran Pendidikan Islam. Prosiding Seminar Antarabangsa Perguruan dan Pendidikan Islam (SEAPPI2012).

Kementerian Pengajian Tinggi. (2006). Modul pembangunan kemahiran insaniah (soft skills) untuk Institut Pengajian Tinggi Malaysia. Serdang. Penerbit Universiti Putra Malaysia. Kementerian Pendidikan Malaysia. (2012). Pelan Pembangunan Pendidikan Malaysia 2013-2025. Bahagian Perancangan dan Penyelidikan Pendididikan, Malaysia.

Kergroach, S. (2017) Industry 4.0: New Challenges and Opportunities for the Labour Market. Foresight and STI Governance, 11(4), 6-8. DOI: $10.17323 / 2500$

2597.2017.4.6.8https://foresightjournal.hse.ru/data/2018/01/09/116053 8630/0-Kergroach-6-8.pdf

Klaus Schwab. (2016). The fourth industrial revolution. Geneva: World Economic Forum. Kurikulum Standard Sekolah Menengah (KSSM) Pendidikan Seni Visual Tingkatan 2. (2016). Kementerian Pendidikan Malaysia: Bahagian Pembangunan Kurikulum

Kurikulum Standard Sekolah Rendah. (2012). Kementerian Pendidikan Malaysia: Bahagian Pembangunan Kurikulum.

Lawrence, GM. (n.d). Digital Printing and Traditional Surface Design Techniques. Abstrak Tesis http://www.lib.ncsu.edu/resolver/1840.16/2948

Marina Maharoff. (2014). Penerapan Kemahiran Insaniah dalam kursus wajib Institut Pendidikan Guru di Malaysia. Tesis Ph.D Tidak diterbitkan. Universiti Putra Malaysia.

Masyuniza Yunos. (2015). Hubungan sikap dan persepsi murid terhadap pembelajaran Bahasa Melayu dengan kemahiran abad ke-21. Jurnal Pendidikan Bahasa Melayu, 5(2), 22- 30.

McMillan, J. H. (2007). Classroom assessment principles and practice for effective standard based instruction. Boston: Pearson Education.

Mohd Saidi Yusof, Che Soh Said, Mohammad Rusdi Mohd Nasir\& Adnan Rozali. (2017). Aplikasi Teknologi Realiti Maya dalam Pembangunan Koswer Rumah Tradisional Melayu Terengganu. KUPAS SENI: Jurnal Seni dan Pendidikan Seni, 5(1), 76 - 86.

Nikitina, L \& Furuoku, F. (2012). Sharp Focus on soft skills: a case study of Malaysian University student's educational expectations. Education Res Policy Prac 1(11), 207-224.

Noor Mohamad Shakil Hameed (2018). Elak jadi korban Industri 4.0. Utusan online http://www.utusan.com.my/rencana/utama/elak-jadikorbanindustri-4-0-1.590945\#ixzz55A7ZbbR7

Raja Abdullah Raja Ismail \& Daud Ismail. (2018). Aplikasi 'Konsep 4c' Pembelajaran Abad Ke-21 Dalam Kalangan Guru Pelatih Pengajian Agama Institut Pendidikan Guru Kampus Dato' Razali Ismail. Asian People Journal, 1(1), 45-65.

Rennert-Ariev, P. (2005). A theoretical model for the authentic assessment of teaching. Practical Assessment Research \& Evaluation, 10(2).

Rohani Arbaa, Hazri Jamil \& Mohammad Zohir Ahmad. (2017). Model Bersepadu Penerapan Kemahiran Abad Ke-21 dalam Pengajaran dan Pembelajaran. Jurnal Pendidikan Malaysia, 42(1), 1-11.

Roslaili Anuar \& Wan Zamani Wan Zakaria. (2015). TPACK dalam Pendidikan Seni Visual: Satu Kajian Mengenai Kesediaan Pelajar Menggunakan EPembelajaran dalam Pembelajaran Pendidikan Seni Visual. Jurnal Seni dan Pendidikan Seni. 3(3), 8-18.

Russell, B \& Deirdre, E. (2012). Developing Preservice Primary Teachers' Confidence and Competence in Arts Education using Principles of Authentic Learning. Australian Journal of Teacher Education, 37(1). http://dx.doi.org/10.14221/ajte.2012v37n1.2

Sabri Mohamad Sharif. (2017). Utusan Online http://m.utusan.com.my/rencana/utama/memahami-peluangrevolusiperindustrian-1.558558

Smith, A \& Anderson J. (2014). AI, Robotics, and the Future of Jobs. Pew Research Center survey reports, demographic studies, and data-driven analysis. http://www.pewinternet.org/2014/08/06/future-of-jobs/ 
Tang Keow Ngang. (2013). Teaching as Collective Work: What Are the Needs of Novice Teachers? Procedia Social and Behavioral Sciences, 93, 19519.

Utusan Melayu. Bakal guru wajib kuasai pengetahuan terkini, celik Industri 4.0 http://www.utusan.com.my/berita/nasional/bakal-guru-wajib-

kuasaipengetahuan-terkini-celik-industri-4-0-

1.623425\#ixzz5GNzWjBJv Wiggins, G. (1998). Educative assessment: Designing assessments to inform and improve student performance. San Francisco: Jossey-Bass.

World Economic Forum. (2016). The Future of Jobs: Employment, Skills and Workforce Strategy for the Fourth Industrial Revolution Global Challenge Insight Report. Switzerland:https://mail.google.com/mail/u/0/\#inbox/1627478048419b 41 ?projector $=1 \&$ messagePartId $=0.2$

Zafir Khan Makhbul (n.d) https://www.bharian.com.my/rencana/muka10/2018/01/370721/5komp onen-tangani-cabaran-industri-40 